\title{
PENGARUH FASILITAS BELAJAR DAN LINGKUNGAN PONDOK PESANTREN AL HUSNA TERHADAP PRESTASI BELAJAR MATA PELAJARAN IPS SISWA KELAS VII C DI MTS. ISLAMIYAH MALO TAHUN AJARAN 2019/2020
}

\author{
Maisyaroh Ayun Sirosa ${ }^{1}$, Sarjono $^{2}$, Ahmad Hariyadi $^{3}$ \\ Prodi Pendidikan Ekonomi Fakultas Pendidikan dan Ilmu Pengetahuan Sosial ${ }^{1-2}$, \\ Prodi Pendidikan Kewarganegaraan Fakultas Pendidikan dan Ilmu Pengetahuan Sosial ${ }^{3}$ \\ Ayunsirosa56@gmail.com ${ }^{1}$, sarjonoikippgribjn@gmail.com ${ }^{2}$, ahmadhariyadi31@yahoo.co.id ${ }^{3}$
}

Received: 02 Oktober 2020; Revised: 21 November 2020; Accepted: 28 Desember 2020 DOI: http://dx.doi.org/10.37905/aksara.7.1.29-36.2021

\begin{abstract}
Abstrak
Tujuan penelitian ini adalahuntuk mengetahui pengaruh fasilitas belajar dan lingkungan pondok pesantren Al Husna terhadap Prestasi Belajar Mata Pelajaran IPS Siswa Kelas VII C Di Mts. Islamiyah Malo.Teknik yang digunakan untuk mengumpulkan data adalah observasi, dan angket/kuesioner.Data dianalisis dengan uji validitas, uji reliabilitas, dan uji hipotesis.Selanjutnya dipaparkan dan ditarik kesimpulan.Hasil penelitian menunjukkan bahwa : (1.)Fasilitas Belajar (X1) memberikan pengaruh dibuktikan dengan thitung sebesar 2,620 dan ttabel dengan nila isignifikannya0,011<0,05. (2.) Lingkungan Pondok Pesantren Al Husna (X2) memberikan pengaruh hal ini dibuktikan dengan thitung=0,742dant tabel signifikannya0,462<0.05.(3.) secara simultan Fasilitas Belajar (X1) Lingkungan Pondok Pesantren Al Husna (X2 )berpengaruh signifikan terhadap Prestasi Belajar Mata Pelajaran IPS SiswaKelas VII C Di Mts. Islamiyah Malo, hal ini diketahui dari hasil pengujian yang menunjukkan thitung sebesar Fhitung= 8,477sama ttabel 0,001, karenasignifikasi lebih kecil dari alpha $(0,001<0,05)$ maka dapat disimpulkan bahwa Ho ditolak dan Ha diterima.
\end{abstract}

Kata Kunci: FasilitasBelajar,LingkunganPondokPesantren Al Husna, Prestasi belajar.

\begin{abstract}
The purpose of this research to know influence between learning facilities and the influence of boarding school environment Al Husna toward student's learning result of VII C of MTs. Islamiyah Malo. To achive that purpose this research using quantitative method with causative and descriptive. The accumulation method that using observation, and questionnaire. The data analyzed with validity test,reliability test,and hypothese. Furthermore the researcher could take the conclusion of this research.The result of this research are : (1.) Learning Facilities $\left(\mathrm{X}_{1}\right)$ give the influence of,as evidenced by $t_{\text {hitung }}$ 2,620 and $t_{\text {tabel }}$ with a significance percentage $0,11<0,05$. (2.) Boarding school environment $\left(\mathrm{X}_{2}\right)$ give the influence of, as evidenced by 0,742 and table significance percentage $0,462<0,05$. (3.) ina simultaneity Learning Facilities and boarding school environment $\mathrm{Al}$ Husna is the influence significance toward study achievement of VII C MTs. Islamiyah Malo, it is known by the result of the testing that showed $\mathrm{f}_{\text {hitung }}=8,477$
\end{abstract}


and $t_{\text {tabel }} 0,001$. because significance is smallest than alpha $(0,00<0,05)$ then could take a conclution that $\mathrm{H}_{\mathrm{o}}$ is rejected and $\mathrm{H}_{\mathrm{a}}$ is accepted

Keyword : learning facilities, boarding school enviroment, learning result.

\section{PENDAHULUAN}

Pendidikan memberikan kita pembekalan yang tidak pernah kita dapat pada masa anak-anak, akan tetapi kita membutuhkannya pada waktu dewasa (Hariyadi \& Darmuki). Pendidikan adalah usaha sadar orang dewasa dan disengaja serta bertanggung jawab untuk mendewasakan anak yang belum dewasa dan berlangsung terus menerus (Hariyadi \& Darmuki, 2019). Pendidikan dianggap begitu penting karena sejak lahir manusia tidak bisa berbuat sesuatu untuk kepentingan dirinya sendiri, memepertahankan hidup maupun merawat dirinya sendiri,sehingga harus bergantung dengan orang lain yang dalam hal ini adalah orang tua. Orang tua sendiri secara kodrati mempunyai kewajiban mendidik anak agar anak dapat hidup mandiri dan lebih baik dari orang tua mereka sesuai dengan yang mereka harapkan. Pendidikan dianggap sanagat penting dalam Undang-Undang RI No,20 Tahun 2003 tentang sistem pendidikan nasional yang berbunyi:

Pendidikan nasional berfungsi untuk mengembangkan kemampuan,membentuk watak serta peradaban bangsa yang bermartabat dalam rangka mencerdaskan kehidupan bangsa, bertujuan untuk mengembangkan potensi peserta didik untuk menjadi manusia yang beriman,bertaqwa Kepada Tuhan Yang Maha Esa,berakhlak mulia,sehat,berilmu,cakap, kreatif, mandiri dan menjadi warga Negara yang demokratis serta bertanggung jawab.

Sehubungan dengan tujuan tersebut maka segenap masyarakat dengan pemerintah berusaha keras untuk mewujudkan usaha tersebut.Usaha yang dilakukan dengan mendirikan lembaga pendidikan Indonesia, baik lembaga formal ataupun non formal sehingga semua lembaga berkewajiban mewujudkan tujuan tersebut.Sekolah merupakan lembaga formal yang memegang peranan yang sangat penting dalam meningkatkan kualitas sumber daya manusia (SDM). Lembaga non formal contohnya yaitu pendidikan di dalam pondok pesantren.

Pesantren sebagai lembaga pendidikan yang memiliki akar kuat indigenous pada masyarakat muslim Indonesia,dalam pejalanannya mampu menjaga dan mempertahankan keberlangsungan dirinya survival system serta memiliki model pendidikan multi aspek. Santri tidak hanya dididik menjadi seseorang yang mengerti ilmu agama, tetapi juga mendapat tempaan kepemimpinan yang alami, kemandirian, kesederhanaan, dan sikap positif lainnya.

Pondok pesantren merupakan rangakaian kata yang terdiri dari pondok dan pesantren. Kata pondok (kamar, gubuk, rumah kecil )yang dipakai dala bahasa Indonesia dengan enekan kesederhanaan bengunannya. Ada pula kemungkinannya kata pondok berasal dari bahasa arab"funduk" yang berarti ruang tempat tidur, wisma atau hotel sederhana. Pada umumnya pondok memang merupakan tepat penampungan sederhana bagi para pelajar yang jauh dari tempat asalnya.Secara garis besar dan umum (awam), 
tipologi pesantren terbagi menjadi dua bagian yaitu, pesantren tradisional dan pesantren modern.Dalam pesantren tradisional, setiap system pengajaran atau materi yang disampaikan masih serba klasik. Pengajaran islam secara mendalam diambil dari kitabkitab kuning masih sangat mendominasi. Sedangkan metode penyajiannya sangat konvensional seperti sorogan, bandongan, ceramah (khutbah), maupun hafalan.

Di pesantren seperti salaf biasannya penggunaan produk-produk hasil peradaban modern semacam radio, televisi, handphone, komputer dan lain sebagainya dilarang keras. Pihak pesantren berargumen melakukan itu demi menjaga santrinya dari desakan globalisasi yang semakin vulgar. Sangat berbeda dengan pesantren modern.salah satu pesantren yang ada di Bojonegoro yaitu yang ada di kecamatan Malo tepatnya didesa Malo.

Muhibbin Syah menambahkan bahwa " disamping faktor-faktor internal dan eksternal siswa,faktor pendekatan belajar juga berpengaruh terhadap taraf keberhasilan proses pembelajaran siswa tersebut. Dengan terpenuhnya fasilitas belajar seperti sarana prasarana dalam belajar dan adanya kondisi lingkungan yang baik dapat mendukung proses pembelajaran sehingga kegiatan belajar mengajar (KBM) berlangsung secara efektif dan efisien. Pencapaian prestasi belajar yang baik menunnjukkan pola-pola, nilainilai, pengertian-pengertian, sikap-sikap, apresiasi dan ketrampilan dan dalam pencapaian hasil belajar yang baik menunjukkan keberhasilan dalam proses pembelajaran, begitu pula sebaliknya tidak tercapainya keberhasilan dalam belajar yang baik menunjukkan kurang berhasilnya dalam proses pembelajaran (Hariyadi, 2018). Dengan demikian pemenuhan dan pengembangan fasilitas dan lingkungan belajar yang baik untuk kelancaran proses belajar perlu diperhatikan oleh setiap sekolah, sebab,terpenuhinya fasilitas dan lingkungan yang baik dapat meminimalisir kesulitan belajar yang dialami oleh peserta didik.

Tingkat kesulitan belajar yang rendah, menciptakan kelancaran proses belajar sehingga terjadi peningkatan prestasi belajar siswa. Demikian dengan MTs Islamiyah Malo yang senantiasa mendorong siswanya untuk berprestasi dengan menyediakan berbagai fasilitas belajar yang memadai dengan pengelolaan yang baik guna menunjang KBM. Disamping itu MTs Islamiyah Malo juga memperhatikan lingkungan tempat belajar siswanya sehingga KBM dapat berlangsung lancr dan meningkatkan prestasi belajar siswa, berdasarkan uraian diatas maka peneliti tertarik untuk mngkaji lebih dalam dengan mengambil judul "Pengaruh Fasilitas Belajar Dan Lingkungan Pondok Pesantren Al Husna Terhadap Prestasi Belajar Mata Pelajaran Ips Siswa Kelas VII C Di Mts. Islamiyah Malo".

\section{METODE PENELITIAN}

Jenis penelitian yang digunakan dalam penelitian ini adalah penelitian kuantitatif deskriptif.Penelitian kuantitatif deskriptif merupakan penelitan yang bertujuan untuk mengetahui besarnya pengaruh antara variabel bebas terhadap variabel terikat.Sugiyono 
berpendapat "penelitian pada variabel independen (variabel yang mempengaruhi) dan dependen (variabel yang dipengaruhi).

Penelitian ini merupakan penelitian kuantitatif karena bertujuan untuk mengetahui pengaruh variabel fasilitas belajar dan lingkungan pondok pesantren terhadap prestasi belajar siswa kelas VII C MTs. Islamiyah Malo.Jenis sampel yang digunakan dalam penelitian ini adalahsampling jenuh. Sampling jenuh merupakan teknik penentuan sampel bila semua anggota popuasi digunakan sebagai sampel

Peneliti menggunakan kuesioner atau angket untuk mengumpulkan data dilapangan supaya mengetahui data tentang fasilitas belajar dan lingkungan pondok pesantren Al Husna. Butir-butir pengembangan dalam angket dikembangkan dari indikator berdasarkan teori yang relevan dari masing-masing variabel penelitian.Untuk keperluan menganalisis secara kuantitatif dan untuk menghindari kesulitan dalam menjawab kuesioner, sehingga responden dapat meneliti lebih teliti maka peneliti memberikan kriteria pada jawaban yang dipilih melalui skala likert. Jawaban dari setiap butir pertanyaan memiliki tingkatan dari yang positilf menjadi sangat negatif, yang berupa kata-kata dengan skor dan pilihan jawaban atas pernyataan sebagai berikut :

Tabel 3.1 Skor Jawaban Angket Penelitian

\begin{tabular}{|r|l|l|}
\hline No. & Jawaban & Skor \\
\hline 1 & Sangat Setuju & 4 \\
\hline 2 & Setuju & 3 \\
\hline 3 & Kurang Setuju & 2 \\
\hline 4 & Tidak Setuju & 1 \\
\hline
\end{tabular}

Dalam menganalisis data peneliti menghitung data dengan menggunakan bantuan program computer SPSS 16.0 for windows.

\section{HASIL DAN PEMBAHASAN}

Hasil

a. Uji validitas

Uji validitas menunjukkan sejauh mana suatu instrument mengukur apa yang ingin diukur. Instrument dikatakan valid apabila memiliki $r>0,3$, apabila harga koefisien korelasi di bawah 0,3 maka dapat disimpulkan bahwa butir instrument tersebut dikatakan tidak valid. Untuk menguji validitas ini dibantu dengan computer progam SPSS versi 16,0 for windows.

\section{b. Uji Reliabilitas}

Pengujian reliabilitas suatu alat ukur mengunakan teknik pengukuran Alpha Chornbach, apabila alat ukur tersebut memiliki koefisien alfa diatas 0,6 maka alat dikatakan reliable. Peneliti menggunakan bantaun program SPSS (Statistical Product and Service Solution) 
16.0 for windows dalam menghitung reliabilitas kedua skala.Berdasarkan perhitungan dengan bantuan SPSS 16,0 for windows, maka dapat ditemukan nilai alpha sebagai berikut.

Table 1 paparan hasil data validitas dan reliabilitas uji coba data fasilitas belajar dan lingkungan pondok pesantren.

\begin{tabular}{|l|l|l|l|l|}
\hline Item & $\begin{array}{l}\text { Person } \\
\text { correlation }\end{array}$ & Keterangan & $\begin{array}{l}\text { Item cronbach } \\
\text { alpha }\end{array}$ & Reliabilitas \\
\hline Item 1 & .510 & Valid & .743 & Reliabel \\
\hline Item 2 & .545 & Valid & & \\
\hline Item 3 & .543 & Valid & & \\
\hline Item 4 & .610 & Valid & & \\
\hline Item 5 & .549 & Valid & & \\
\hline Item 6 & .510 & Valid & & \\
\hline Item 7 & .575 & Valid & & \\
\hline Item 8 & .627 & Valid & & \\
\hline Item 9 & .584 & Valid & & \\
\hline Item 10 & .458 & Valid & & \\
\hline Item 11 & .668 & Valid & & \\
\hline Item 12 & .701 & Valid & & \\
\hline Item 13 & .409 & Valid & .744 & \\
\hline Item 14 & .646 & Valid & & \\
\hline Item 15 & .600 & Valid & & \\
\hline Item 16 & .424 & Valid & & \\
\hline Item 17 & .553 & Valid & & \\
\hline Item 18 & .521 & Valid & & \\
\hline Item 19 & .569 & Valid & & \\
\hline Item 20 & .650 & Valid & & \\
\hline Item 21 & .632 & Valid & & \\
\hline Item 22 & .647 & Valid & & \\
\hline Item 23 & .585 & Valid & & \\
\hline Item 24 & .577 & Valid & & \\
\hline Item 25 & .646 & Valid & & \\
\hline Item 26 & .530 & Valid & & \\
\hline Item 27 & .544 & Valid & & \\
\hline Item 28 & .618 & Valid & & \\
\hline & & & & \\
\hline
\end{tabular}

\section{a. Hasil Uji Normalitas}

dalam uji ini peneliti menggunakan signifikansi dibagian Shapiro wilk.Untuk menguji validitas ini dibantu dengan computer progam SPSS versi 16, Ofor windows. 
Tabel 2 hasil uji normalitas

Tests of Normality

\begin{tabular}{|l|l|l|l|l|l|l|}
\hline & \multicolumn{3}{|l|}{ Kolmogorov-Smirnov ${ }^{\mathrm{a}}$} & \multicolumn{3}{l|}{ Shapiro-Wilk } \\
\cline { 2 - 7 } & $\begin{array}{l}\text { Statisti } \\
\text { c }\end{array}$ & Df & Sig. & Statistic & Df & Sig. \\
\hline Y & .096 & 55 & $.200^{*}$ & .945 & 55 & .014 \\
\hline
\end{tabular}

a. Lilliefors Significance Correction

*. This is a lower bound of the true significance.

Data tersebut berdistribusi normal dengan nilai 0.014>0.05 untuk variable fasilitas belajar dan lingkungan pondok pesantren Al Husna

b. Koefisien Diterminasi

Tabel 3 koefisien diterminasi Model Summary

\begin{tabular}{|l|l|l|l|l|}
\hline $\begin{array}{l}\text { Mode } \\
1\end{array}$ & $\mathrm{R}$ & $\mathrm{R}$ Square & $\begin{array}{l}\text { Adjusted } \\
\text { Square }\end{array}$ & $\begin{array}{l}\text { Std. Error of the } \\
\text { Estimate }\end{array}$ \\
\hline 1 & $.496^{\mathrm{a}}$ & .246 & .217 & 3.22671 \\
\hline
\end{tabular}

a. Predictors: (Constant), Fasilitas Belajar( $\left.\mathrm{X}_{1}\right)$,Lingkungan Pondok Pesantren $\mathrm{Al}$ Husna $\left(\mathrm{X}_{2}\right)$.

Sebelum dilakukan pengujian hipotesis terlebih dahulu dilakukan analysis korelasi yang diperoleh dari output regresi. Berdasarkan tabel Model Summary diatas, hubungan antara variabel fasilitas belajar dengan prestasi belajar diperoleh nilai R2 ( R Square ) sebesar 0,246,dengan demikian dapat dikatakan bahwa hubungan antara variabel lingkungan pondok pesantren Al Husna dan fasilitas belajar terhadap prestasi belajar menunjukkan hubungan yang cukup.

\section{Pembahasan}

Hasil dari analisis data membuktikan bahwa variable fasilitas belajar(X1) berpengaruh terhadap prestasi belajar siswa,hal ini ditujukkan dengan nilai $t_{\text {hitung }}=2,620$.

Hasil perhitungan $t_{\text {hitung }}$ 2,620lebih besar dari $t_{\text {tabel }}$ yaitu dilihat dari nilai signifikannya hasil hitungan SPSS yaitu $0,011<0,05$. Maka dari hasil analisis data dapat disimpulkan bahwa $\mathrm{H}_{\mathrm{a}}$ diterima dan $\mathrm{H}_{\mathrm{O}}$ ditolak ini menunjukkan bahwa secara parsial fasilitas belajar berpengaruh signifikan terhadap prestasi belajar siswa kelas VII C MTs. Islamiyah Malo.

pengujian hipotesis kedua yaitu lingkungan pondok pesantren (X2)dengan cara membandingkan antara hasil dari thitung dengan $t_{\text {tabel. }}$. Dari tabel koefisien diatas diperoleh hasilt $_{\text {hitung }}=0,742>0,462$.

Diketahui $t_{\text {hitung }}=0,742>t_{\text {tabel }} 0,462$,yang diambil dari nilai signifikan hasil hitung SPSS. Jadi dari data analis diatas dapat disimpulkan bahwa secara parsial lingkungan 
pondok pesantren Al Husna berpengaruh terhadap prestasi belajar siswa kelas VII C MTs. Islamiyah Malo.

Muhibbin Syah menambahkan bahwa " disamping faktor-faktor internal dan eksternal siswa,faktor pendekatan belajar juga berpengaruh terhadap taraf keberhasilan proses pembelajaran siswa tersebut. Dengan terpenuhnya fasilitas belajar seperti sarana prasarana dalam belajar dan adanya kondisi lingkungan yang baik dapat mendukung proses pembelajaran sehingga kegiatan belajar mengajar (KBM) berlangsung secara efektif dan efisien.

\section{SIMPULAN}

Berdasarkan hasil penelitian dan pembahasan maka dapat diambil kesimpulan sebagai berikut:

1. Secara parsial faslitas belajar berpengaruh terhadap prestasi belajar siswa kelas VII C di MTs. Islamiyah Malo. ,pengujian hipotesis pertama dilakukan dengan cara membandingkan antara hasil dari thitung . maka diperoleh nilai $t_{\text {hitung }}=2,620$.

Hasil perhitungan thitung 2,620 lebih besar dari ttabel yaitu dilihat dari nilai signifikannya hasil hitungan SPSS yaitu $0,011<0,05$. Maka dari hasil analisis data dapat disimpulkan bahwa $\mathrm{H}_{\mathrm{a}}$ diterima dan $\mathrm{H}_{\mathrm{o}}$ ditolak ini menunjukkan bahwa secara parsial fasilitas belajar berpengaruh signifikan terhadap prestasi belajar siswa kelas VII C MTs. Islamiyah Malo.

Dengan demikian dapat disimpulkan bahwa semakin baik fasilitas belajar maka akan semakin baik pula prestasi belajar siswa.

. 2. secara parsial lingkungan pondok pesantren $\mathrm{Al}$ Husna berengaruh terhadap prestasi siswa kelas VII C,hal ini dibuktikan dengan hasil hitung yang menyatakan bahwa diperoleh hasilthitung $=0,742>0,462$

Diketahui $t_{\text {hitung }}=0,742>t_{\text {tabel }} 0,462$,yang diambil dari nilai signifikan hasil hitung SPSS. Jadi dari data analis diatas dapat disimpulkan bahwa secara parsial lingkungan pondok pesantren Al Husna berpengaruh terhadap prestasi belajar siswa kelas VII C MTs. Islamiyah Malo.

Karena lingkungan pondok pesantren Al Husna yang sering memperhatikan belajar siswa dipondok maupun disekolah, dengan demikian dapat disimpulkan bahwa semakin baik lingkungan pondok pesantren yang ada disekitar siswa maka akan semakin baik pula prestasi belajar siswa.

3. Secara simultan fasilitas belajar dan lingkungan pondok pesantren berpengaruh signifikan terhadap prestasi belajar mata pelajaran IPS siswa kelas VII C di MTs. Islamiyah Malo. diperoleh nilai $F_{\text {hitung }}=8,477$ dengan demikian jika dilihat dari nilai signifikannya,hasil pengujian menunjukkan pengaruh yang bersifat positif atau berbanding lurus. Oleh karena itu dapat disimpulkan dari hasil pengujian tersebut menunjukkan bahwa variabel fasilitas belajar dan lingkungan pondok pesantren $\mathrm{Al}$ Husna secara bersama sam (simultan) berpengaruh terhadap prestasi belajar.Artinya semakin lengkapnya fasilitas belajar dan lingkungan pondok pesantren Al Husna yang baik maka prestasi belajar siswa juga semakin baik. 


\section{DAFTAR PUSTAKA}

Ahmadi Abu dan Nur Uhbiyati,1991.Ilmu pendidikan,(Jakarta : Rinekecipta)

Arikunto Suharsimi,Prosedur Penelitian Suatu Pendekatan Praktik, (Jakarta:Rieneke Cipta,2006)

Bafadal Ibrahim, Manajemen Perlengkapan Sekolah : Teori dan aplikasinya, (Jakarta: Bumi Aksara, 2003).

Darmuki, Agus. 2014. Pengintegrasian Pendidikan Budaya dan Karakter Bangsa dalam Pengajaran Matakuliah Bahasa Indonesia di Perguruan Tinggi IKIP PGRI Bojonegoro. Seminar Nasional AJPBSI. Vol. 3(1), 79-82.

Hariyadi, A. \& Darmuki, A. 2019. Prestasi dan Motivasi Belajar dengan Konsep Diri. Prosiding Seminar Nasional Penguatan Muatan Lokal Bahasa Daerah sebagai Pondasi Pendidikan Karakter Generasi Milenial. PGSD UMK 2019, 280-286.

Hariyadi, Ahmad. 2018. Use of Smart Ladder Snake Media to Improve Student Learning Outcomes of IV Grade Students of State Elementary School I Doropayung Pancur Rembang. Refleksi Edukatika. Vol. 9(1), 107-111.

Hasan Iqbal, Analisis Data Penelitian Dengan Statistik. (Jakarta: Bumi Aksara, 2006)

Syah Muhibbin, psikologi belajar, (Jakarta: logos,1999)

Sulaiman Wahid, Analisis Regresi Berganda Menggunakan SPSS (Contoh Kasus dan Pemecahannya, (Yogyakarta: Andi, 2004)

Sanjaya Wina, Strategi Pembelajaran Berorientasi Standar Proses Pendidikan, (Jakarta: Kencana,2009)

Thobroni. M, Belajar dan Pembelajaran : Teori dan Praktik, (Yogyakarta; Ar-Ruuz, Media,2015)

Wahidmurni,Cara Mudah Menulis Proposal dan Laporan Penelitian Lapangan, (Malang : UM press, 2008) 